\title{
Lithostratigraphy and structure of the Dharan-Mulghat area, Lesser Himalayan sequence, eastern Nepal Himalaya
}

\author{
*L. K. Rai ${ }^{1}$, K. K. Acharya ${ }^{2}$ and M. R. Dhital ${ }^{2}$ \\ ${ }^{1}$ Central Campus of Technology, Tribhuvan University, Dharan, Sunsari, Nepal \\ ${ }^{2}$ Central Department of Geology, Tribhuvan University, Kirtipur, Kathmandu, Nepal \\ (*E-mail: lalitrai83@gmail.com)
}

\begin{abstract}
The Dharan-Mulghat area of the eastern Nepal can be divided into three tectonic units: the Higher Himalayan Crystallines, the Lesser Himalayan Sequence and the Siwaliks from north to south separated by the Main Central Thrust (MCT) and Main Boundary Thrust (MBT), respectively. The Lesser Himalayan Sequence is divided into two groups separated by Chimra Thrust: the Bhedetar Group and the Dada Bajar Group. The Bhedetar Group includes the Raguwa Formation, the Phalametar Quartzite, the Churibas Formation, the Sangure Quartzite, and the Karkichhap Formation from the bottom to top, respectively; overthrusted by the Dada Bajar Group consisting: the Ukhudanda Formation, the Mulghat Formation, the Okhre Formation, and the Patigau Formation, from lower to upper sections, respectively along the Chimra Thrust and the Bhorleni Formation as an individual formation overthrusted by Bhedetar Group along the Chhotimorang Thrust. The Main Central Thrust, the Main Boundary Thrust, the Chimra Thrust and the Chhotimorang Thrust are the major faults in Dharan-Mulghat area. The Leutiphedi Anticline and the Malbase Syncline are the major folds in the study area plunging towards east. The trend/plunge of anticline and syncline are $131^{\circ} / 24^{\circ}$ and $096^{\circ} / 09^{\circ}$ respectively. The microstructural study in the quartz grains reveals a sharp difference in the history across the MCT; dynamic in the rocks of the Lesser Himalayan Sequences and static in the rocks of the Higher Himalayan Crystallines.
\end{abstract}

Keywords: Lithostratigraphy, structure, eastern Nepal Himalaya

Received: 2 October 2015

Revision received: 3 April 2016

\section{INTRODUCTION}

Intracontinental collision between the Indian and the Eurasian plates since $\sim 55$ Ma gave rise to the rugged topography and dynamic geology of the Himalaya. Tectonomorphologically, the whole Himalaya can be divided into different longitudinal units having unique morphological, geological and evolutionary characteristics (Gansser 1964, Le Fort 1975, Valdiya 1980). From south to north, they are: Terai plain (Indo-Gangetic Plain), Sub Himalaya (Siwalik); Lesser Himalaya; Higher Himalaya Crystallines (HHC); Tibetan-Tethys Himalaya and Indus Tsangpo Suture Zone, respectively. The Nepal Himalaya occupies approximately $800 \mathrm{~km}$ of the Himalayan belt extending along east- west direction. The present study area (Dharan-Mulghat) lies on the eastern part of the Nepal Himalaya (Fig. 1) where the Lesser Himalaya is pinched due to the thrusting of the Higher Himalaya Crystallines over the Lesser Himalaya, dispite of some windows such as Arun Valley Window (Bordet 1961). Hashimoto et al. (1973) worked from the Dudh Koshi to the Mechi River of the eastern Nepal and established the relation of geology and topography of the Churia Range, the Midland, the Lesser Himalaya and the Great Himalaya. The area between Takure Village near Dharan and the Bhalu Khola in the Sindhuli District was studied by Bashyal (1978) and divided it into seven lithologic units. Sunuwar (1993) studied the geology of the Tribeni-Barahakshetra area and divided the area into five groups. Timsina (2011) worked around Mulghat-Hile area and divided the area into Higher Himalayan Crystallines with two formations and the Lesser Himalaya Sequence with seven formations. Dhital (2015) described the geology of TribeniDharan-Dhankuta area and divided the Lesser Himalaya into eight formations. The present study is focused on establishing the lithostratigraphy and preparing a detailed geological map of the area. Around the Dharan-Mulghat area high grade kyanitesillimanite bearing Higher Himalayan gneisses are thrust over the Lesser Himalayan Sequence along the Main Central Thrust (MCT). The Lesser Himalayan Sequence pinches towards east section compared to west section.

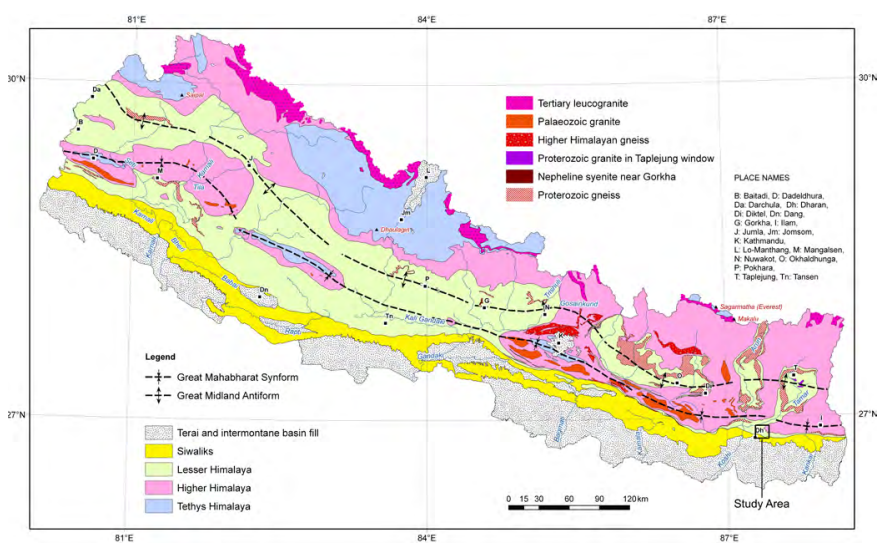

Fig. 1: Geological map of Nepal showing location of the study area (After Dhital, 2015). 
Rai et al.

\section{LITHOSTRATIGRAPHY}

Tectonically the area is separated into three broad divisions: the Higher Himalayan Crystallines; the Lesser Himalayan Sequence and the Siwaliks. The Main Central Thrust (MCT) separates the Higher Himalayan Crystallines from the Lesser Himalayan Sequence, whereas the Lesser Himalayan Sequence is separated by the Main Boundary Thrust (MBT) from the Siwaliks. The Chimra Thrust (CT), almost parallel to

Table 1: Tectono-Lithostratigraphy of the study area the MCT, divides Lesser Himalayan Sequence into two groups, cutting lower unit discordantly. The geological map and the cross-section of the present study area are shown in Fig. 2 and Fig. 4 respectively. The tectono-lithostratigraphy of the study area is given in Table 1. In the present study, the stratigraphy is compared with the established units of central Nepal published by Stöcklin and Bhattarai (1977) and Stöcklin (1980). The stratigraphy is also compared with western Nepal by proposed by Sakai $(1983,1985)$. The correlation of the different units are shown in Table 2.

\begin{tabular}{|c|c|c|c|c|c|}
\hline \multicolumn{3}{|c|}{ Formation } & Lithology & Thickness (m) & Age \\
\hline \multicolumn{3}{|c|}{ Higher Himalayan Crystalline } & $\begin{array}{l}\text { Grey feldspathic schist, parallel laminated light } \\
\text { grey to white quartzite and grey banded gneiss. }\end{array}$ & & \\
\hline \multicolumn{6}{|c|}{ - } \\
\hline \multirow{12}{*}{ 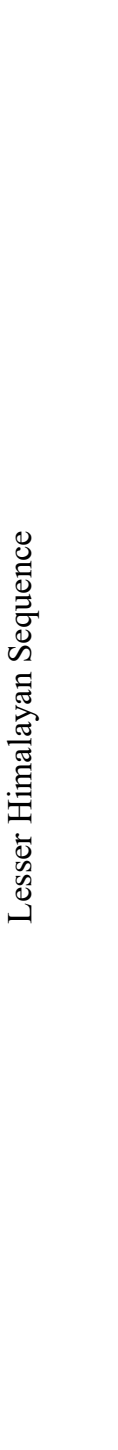 } & \multirow{4}{*}{ 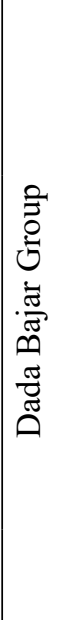 } & \begin{tabular}{|l} 
Patigau \\
Formation \\
with Majite \\
Quartzite \\
\end{tabular} & $\begin{array}{l}\text { Greenish grey laminated calcareous schist } \\
\text { and laminated chlorite-garnet schist. Thin to } \\
\text { medium bedded yellowish green quartzite beds. }\end{array}$ & 1150 & \multirow{4}{*}{ 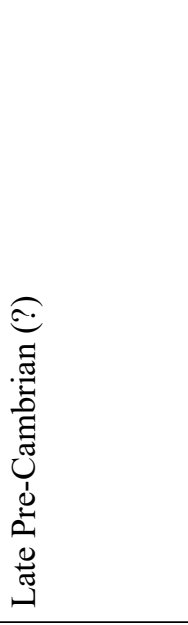 } \\
\hline & & $\begin{array}{l}\text { Okhre } \\
\text { Formation }\end{array}$ & $\begin{array}{l}\text { Dark greenish grey crenulated phyllite with } \\
\text { sporadic greenish grey quartzite and crenulated } \\
\text { chlorite schist. }\end{array}$ & 800 & \\
\hline & & $\begin{array}{l}\text { Mulghat } \\
\text { Formation } \\
\text { with } \\
\text { Arubote } \\
\text { Quartzite }\end{array}$ & $\begin{array}{l}\text { Black carbonaceous slate-phyllite laminated } \\
\text { graphitic schist with quartz veins. Parallel } \\
\text { laminated pale-yellow calcareous quartzite. }\end{array}$ & $>575$ & \\
\hline & & $\begin{array}{l}\text { Ukhudanda } \\
\text { Formation }\end{array}$ & $\begin{array}{l}\text { Dark-grey, medium to thick bedded, crenulated } \\
\text { mylonitic schist with sheared quartz veins. }\end{array}$ & 1050 & \\
\hline & \multicolumn{5}{|c|}{ 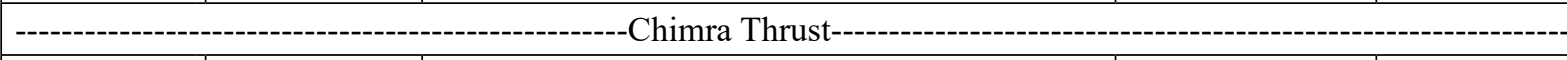 } \\
\hline & \multirow{5}{*}{ 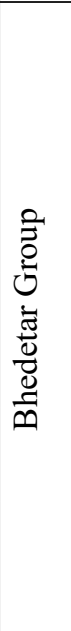 } & $\begin{array}{l}\text { Karkichhap } \\
\text { Formation }\end{array}$ & $\begin{array}{l}\text { Black shale-slate, medium to thick bedded fine } \\
\text { grained grey quartzite and sporadically purple } \\
\text { phyllite. }\end{array}$ & $>60$ & \multirow{5}{*}{ 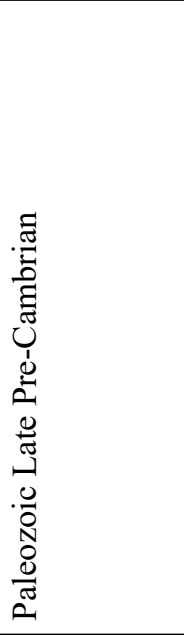 } \\
\hline & & $\begin{array}{l}\text { Sangure } \\
\text { Quartzite }\end{array}$ & $\begin{array}{l}\text { Fine-grained, medium to thick bedded white } \\
\text { and pink quartzite with phyllite parting highly } \\
\text { fracture. }\end{array}$ & $>400$ & \\
\hline & & $\begin{array}{l}\text { Churibas } \\
\text { Quartzite }\end{array}$ & $\begin{array}{l}\text { Dark-green to purple phyllite, green } \\
\text { metasandstone and fine to medium grained } \\
\text { chloride rich quartzite. }\end{array}$ & $\sim 1050$ & \\
\hline & & \begin{tabular}{|l|} 
Phalametar \\
Formation \\
\end{tabular} & $\begin{array}{l}\text { Pale to light grey and cream coloured quartzite } \\
\text { with phyllite parting and intercalations. }\end{array}$ & 300 & \\
\hline & & $\begin{array}{l}\text { Raguwa } \\
\text { Formation }\end{array}$ & $\begin{array}{l}\text { Dark grey and black highly foliated } \\
\text { carbonaceous phyllite and slate with grey } \\
\text { quartzite alterations. }\end{array}$ & $>550$ & \\
\hline & \multicolumn{5}{|c|}{ 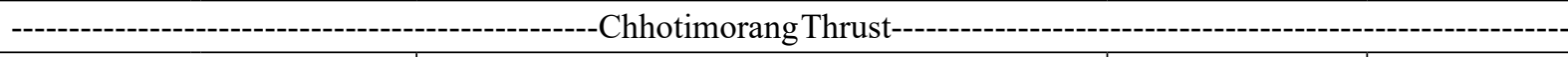 } \\
\hline & \multicolumn{2}{|c|}{ Bhorleni Formation } & $\begin{array}{l}\text { Light green meta-sandstone with phyllite } \\
\text { parting. }\end{array}$ & $\sim 750$ & Miocene \\
\hline \\
\hline \multicolumn{2}{|l|}{ Siwalik } & $\begin{array}{l}\text { Middle } \\
\text { Siwalik }\end{array}$ & $\begin{array}{l}\text { Medium grained, pepper and salt appearance } \\
\text { sandstone. }\end{array}$ & & $\begin{array}{l}\text { Middle } \\
\text { Miocene to } \\
\text { Pliocene }\end{array}$ \\
\hline
\end{tabular}




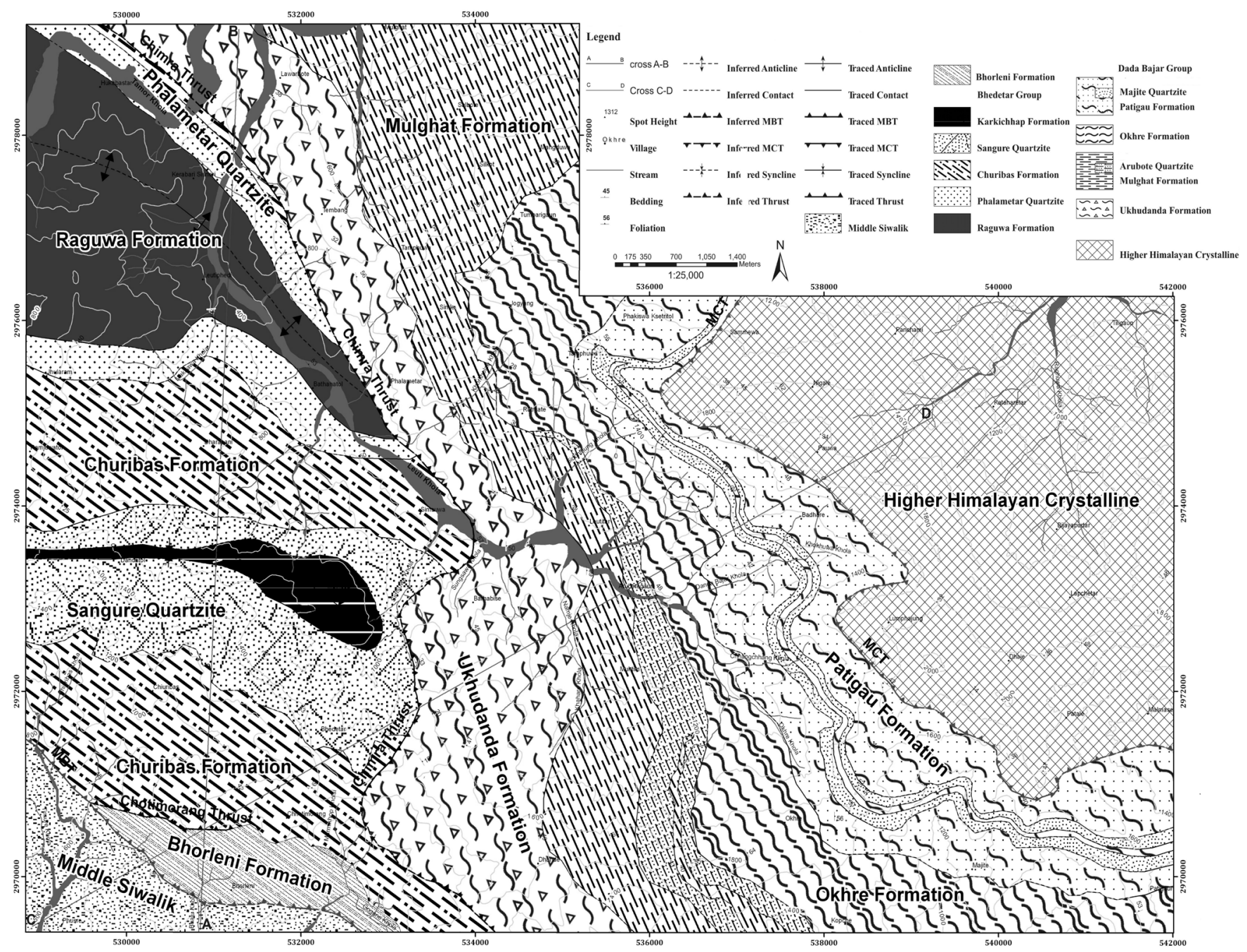

Fig. 2: Geological Map of Dharan-Mulghat area (geological cross sections along A-B and C-D are presented in Fig. 4).

\section{Siwalik}

In the present study area the Middle Siwalik represents the Siwalik or Sub Himalaya rock. It consists of fine to medium grained, medium bedded sandstone interbedded with dark brown variegated mudstone (Fig. 2). The proportion of sandstone to mudstone is 80:20, approximately.

\section{Lesser Himalayan Sequence}

The Lesser Himalayan Sequence is mainly composed of low to medium grade metamorphic rocks, which is divided into ten geological formations viz. the Bhorleni Formation, the Raguwa Formation, the Phalametar Quartize, the Churibas Formation, the Sangure Quartzite, the Karkichhap Formation, the Ukhudanda Formation, the Mulghat Formation, the Okhre Formation and the Patigau Formation (Fig. 2), respectively from bottom to top. Among these ten formations first nine formations are divided into two groups and the Bhorleni Formation as an individual. The two groups are the Bhedetar Group and the Dada Bajar Group which are separated by the Chimra Thrust (Fig. 2).

\section{Bhorleni Formation}

This formation is named after the Bhorleni village located in the north of Dharan. It is separated from the Siwalik rocks by the MBT towards south-west and from the Bhedetar Group of rocks by the Chhotimorang Thrust towards north. The main rock types of this formation are light green metasandstone with greenish-grey phyllite parting and greenish-grey to purple phyllite. The rock of this formation is well observed at the foot-trail north from the Shikarbas village towards the Koshi Highway and at the landslide near the Shivajhatta temple. The thickness of this formation is about $750 \mathrm{~m}$. Lithostratigraphically, this formation can be compared to Tamrang Formation of Gondwana Sequence of Barahakshetra area (Sunuwar 1993) and Dubring Formation of PiuthanSallyan area (Tater 1964, Sakai 1983, Dhital and Kizaki 1987).

\section{Bhedetar Group}

The Bhedetar Group consists of low grade metamorphic rocks divided into five formations viz. the Raguwa Formation, the Phalametar Quartzite, the Churibas Formation, the Sangure Quartzite, and the Karkichhap Formation from the bottom to top and lies on the western section of the study area (Fig. 2). 
This group is separated from the Bhorleni Formation by the Chhotimorang Thrust in the south-west and from the rocks of the Dada Bajar Group by the Chimra Thrust in the north-east. The average thickness of this group is about $>2360 \mathrm{~m}$.

\section{Raguwa Formation}

This formation is named after the Raguwa Khola (Sunuwar 1993). This is the oldest and the lowermost formation of the Bhedetar Group forming the core of Leutiphedi Anticline (Fig. 4). The main lithology of this formation is the dark grey to black highly foliated carbonaceous phyllite and slate with grey quartzite alterations and calcareous phyllite bands. Cross laminations (Fig. 3a) and S-type folds (Fig. 3b) are observed in this formation. This formation is equivalent to the Kuncha Formation (Maskey 1987). The thickness of this formation is $>550 \mathrm{~m}$.

\section{Phalametar Quartzite}

The name of this formation is derived from the Phalametar village situated on the right bank of the Leuti Khola (Sunuwar 1993). The Phalametar Quartzite conformably lies over the Raguwa Formation forming the Leutiphedi Anticline. The main lithology of this formation is thick-bedded, medium to fine grained, massive, and pale to light grey, cream coloured quartzite with phyllite parting and intercalations. The thickness of this formation is $300 \mathrm{~m}$. Lithostratigraphicaly this formation can be compared to the Fagfog Quartzite of central Nepal (Stöcklin and Bhattarai 1977, Stöcklin 1980) and the Naudanda Quartzite of western Nepal (Sakai 1983, 1985).

\section{Churibas Formation}

The name of this formation is derived from the Churibas village (Sunuwar 1993). The Churibas Formation lies over the Phalametar Quartzite and participates in both limbs of Malbase Syncline and Leutiphedi Anticline (Fig. 4). The main lithology of this formation is the dark-green to grey-green phyllite, dark red-purple phyllite, green metasandstone and fine to medium grained chlorite rich quartzite. Few bands of amphibolites are also observed. In the southern limb calcareous slate are also observed occasionally. The proportion of phyllite dominants other rock type and posses well developed foliation and shining lusture. The average thickness of this formation is $\sim 1050 \mathrm{~m}$. Lithostratigraphicaly this formation can be compared to the Dandagoan Phyllite of central Nepal (Stőcklin and Bhattarai 1977, Stöcklin 1980) and the upper Heklang Formation of western Nepal (Sakai 1983, 1985)

\section{Sangure Quartzite}

The name of this formation has been derived from the Sangure ridge (Tater 1964, Sunuwar 1993). This formation transitionally rests over the Churibas Formation. The Sangure Quartzite is represented by the thick-bedded, fine to medium grained, highly fractured, dominantly of milky white quartzite and thin bedded pink quartzite with intercalation of pink-purple phyllite. Ripple marks both wave and current are observed in the quartzite of this formation (Fig. 3c). The thickness of this formation is $>400 \mathrm{~m}$. Lithostratigraphicaly this formation can be compared to the Purebesi Quartzite of central Nepal (Stöcklin and Bhattarai 1977, Stöcklin 1980) and the upper Virkot Formation of western Nepal (Sakai 1983, 1985)

\section{Karkichhap Formation}

The Karkichhap Formation is the youngest formation of the Bhedetar Group. The name is derived after the village named Karkichhap (Sunuwar 1993). This formation transitionally rests over the Sangure Quartzite and lies at the core of the Malbase Syncline (Fig. 4). The main lithology of this formation are black shale or slate, medium to thick-bedded fine grained, grey quartzite and sporadically purple phyllite. Mud-cracks are well observed in the slate and phyllite of this formation, which is distorted due to intense folding (Fig. 3d). The average thickness of this formation is $>60 \mathrm{~m}$. Lithostratigraphicaly this formation can be compared to the Benighat Slate of central Nepal (Stöcklin and Bhattarai 1977, Stöcklin 1980) and the Ramdighat Formation (?) of western Nepal (Sakai 1983, 1985).

\section{Dada Bajar Group}

The rocks of the Dada Bajar Group consist of four formations viz. the Ukhudanda Formation, the Mulghat Formation, the Okhre Formation and the Patigau Formation from bottom to top, respectively. The rocks of this group are more metamorphosed as compared to the rocks of the Bhedetar Group. The rocks of the Dada Bajar Group is separated from the Bhedetar Group of rocks by the Chimra Thrust, which extends north-west to south-east direction and lies at the central part of the study area (Fig. 2). The Main Central Thrust separates the rocks of this Group from the Higher Himalayan Crystalline in the north-east section of the study area. The average thickness of this group is about $>3575 \mathrm{~m}$. Lithostratigraphicaly this group of rock can be compared to the Kuncha Formation (?) of central Nepal (Stöcklin and Bhattarai 1977, Stöcklin 1980) and the Andhi Formation (?) of western Nepal (Sakai 1983, 1985).

\section{Ukhudanda Formation}

This formation is named after the village Ukhudanda, which lies near the confluence of the Tamor Nadi and the Leuti Khola (Sunuwar 1993). This formation discordantly overlies the rocks of the Bhedetar Group along the Chimra Thrust. The main lithology representing this formation is the greenish grey to dark-grey, thin to thick-banded crenulated mylonitic schist with numerous quartz veins. The quartz veins are highly sheared and folded showing the concordant relationship with foliation. Augen shaped feldspar and quartz with diameter less than $1 \mathrm{~mm}$ are distributed throughout the rocks. Augen shaped grains are dominant at the lower portion whereas quartz veins are dominant at the upper portion. The average thickness of this formation is $1050 \mathrm{~m}$.

\section{Mulghat Formation with Arubote Quartzite}

The grey mylonitic schist of the Ukhudanda Formation 
gradually passes upward to grey to black graphitic slate of the Mulghat Formation. The name of the formation is derived from the Mulghat Bajar in the Tamor valley (Sunuwar 1993). This formation mainly consists of finely laminated black carbonaceous slate or phyllite, thinly laminated graphitic schist with quartz veins in the lower portion and parallel-laminated, thickly bedded, pale yellow to white, light grey very fine and dense calcareous quartzite bands alternating with dark grey to black slate or phyllite in the upper portion as Arubote Quartzite, name derived from the Arubote village at the bank of the Leuti River which pinches from south to north (Fig. 2). Amphibolites bands are also observed in certain areas. The thickness of this formation is $>575 \mathrm{~m}$.

\section{Okhre Formation}

This formation is named after the Okhre village situated at the Bhedetar-Rajarani road, and rests over the Mulghat Formation. The lithology is dark greenish grey, crenulated phyllite with sporadic greenish grey quartzite and greenish grey, crenulated chlorite schist bands with quartz veins (very rare). The quartz veins are intensely folded. Graphitic schist containing euhedral brown garnets observed in upper portion of the formation. The total thickness of this formation is $800 \mathrm{~m}$.

\section{Patigau Formation with Majite Quartzite}

This formation is named after the Patigau village located at the south-east part of the study area. It rests over the Okhre Formation and is the youngest formation of the Dada Bajar Group. It is separated from Higher Himalayan Crystalline by Main Central Thrust towards north-east. The main lithology of this formation is the greenish grey, laminated calcareous schist; laminated chlorite-garnet schist and thin to medium-bedded yellowish green quartzite bed. The laminated calcareous schist is well observed at the lower section of the formation with sporadic thin laminated grey limestone and dolomite, which was highly folded (Fig. 3e). At the middle portion of this formation, thin to medium beds of pale yellow chlorite rich quartzite with grey schist partings was observed here referred as the Majite Quartzite (Fig. 2 and 3f) which is sporadically calcareous. In between quartzite beds a thick succession of dark grey to green, crenulated garnet-chlorite schist and graphitic schist is present. It is highly sheared and full of folded quartz lenses and sheared boudins (swell and pinch structure) (Fig. $3 \mathrm{~g}$ ). In the upper section black greenish grey garnet-biotite schist is dominant and some marble bands are also observed. The graphitic nature of highly sheared schist and presence of garnet indicates the presence of MCT nearby. The average thickness of this formation is $1150 \mathrm{~m}$.

Table 2: Correlation and comparison of the present study area (Lesser Himalayan Sequence) with the Lesser Himalayan Sequence of central and western Nepal.

\begin{tabular}{|c|c|c|c|c|}
\hline \multicolumn{2}{|c|}{$\begin{array}{l}\text { Present Study area } \\
\text { (Rai et al. 2016) }\end{array}$} & \begin{tabular}{|l|}
$\begin{array}{l}\text { Central Nepal } \\
\text { (Stöcklin and Bhattarai 1977, Stöcklin 1980) }\end{array}$ \\
\end{tabular} & \multicolumn{2}{|c|}{$\begin{array}{l}\text { Western Nepal } \\
\text { (Sakai 1983, 1985) }\end{array}$} \\
\hline \multicolumn{2}{|c|}{ Bhorleni Formation } & & \multicolumn{2}{|c|}{ Dumri Formation } \\
\hline \multicolumn{5}{|c|}{----------Chhotimorang Thrust--------- } \\
\hline \multirow{6}{*}{ 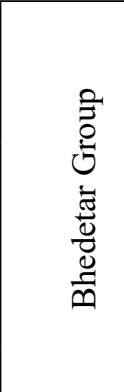 } & Karkichhap Formation & Benighat Slate & Ramdi & Formation (?) \\
\hline & Sangure Quartzite & Purebesi Quartzite & Upper & \multirow{2}{*}{ Virkot Formation } \\
\hline & \multirow[t]{2}{*}{ Churibas Formation } & \multirow[t]{2}{*}{ Dandagaon Phyllite } & Lower & \\
\hline & & & \multicolumn{2}{|c|}{ Heklang Formation } \\
\hline & Phalametar Quartzite & Fagfog Quartzite & \multicolumn{2}{|c|}{ Naudanda Quartzite } \\
\hline & Raguwa Formation & \multirow{6}{*}{ Kuncha Formation (?) } & \multirow{6}{*}{\multicolumn{2}{|c|}{ Andhi Formation (?) }} \\
\hline \multicolumn{2}{|c|}{\begin{tabular}{|l|}
--------------Chimra Thrust------------ \\
\end{tabular}} & & & \\
\hline \multirow{4}{*}{ 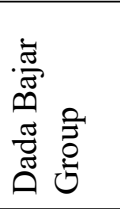 } & Patigau Formation & & & \\
\hline & Okhre Formation & & & \\
\hline & Mulghat Formation & & & \\
\hline & Ukhudanda Formation & & & \\
\hline
\end{tabular}

\section{Higher Himalayan Crystalline}

The Higher Himalayan Crystalline (HHC) is separated from the Lesser Himalaya Sequence by MCT. The rocks of HHCs are not further divided into subdivision in present study area. The highly sheared and garnet bearing rocks of the Patigau Formation gradually change to grey feldspathic schist, indicating the Higher Himalayan Crystalline. The main lithology is faldspathic schist, parallel-laminated light grey to white quartzite and massive beds of grey banded gneiss. The rocks of the Higher Himalayan Crystalline are well observed around Danda Bajar area, the north-eastern part of present study area. Blue-green kyanite blades were observed in the feldspathic schist and banded gneiss (Fig. 3h). In some places tourmaline bearing pegmatite veins were observed. 

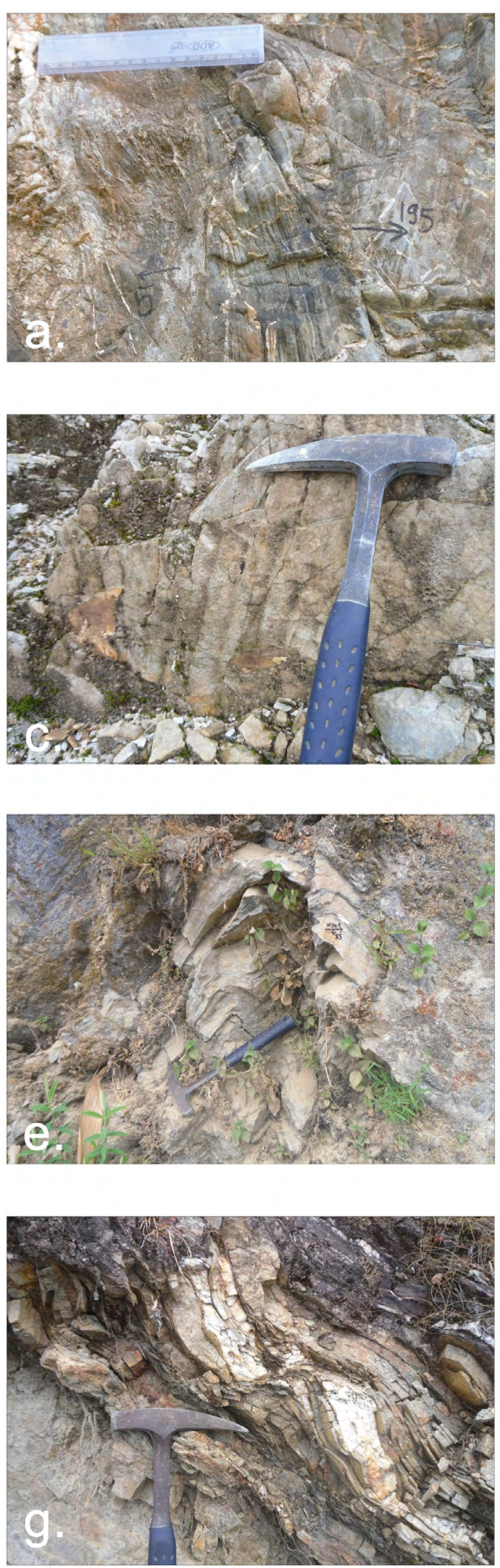
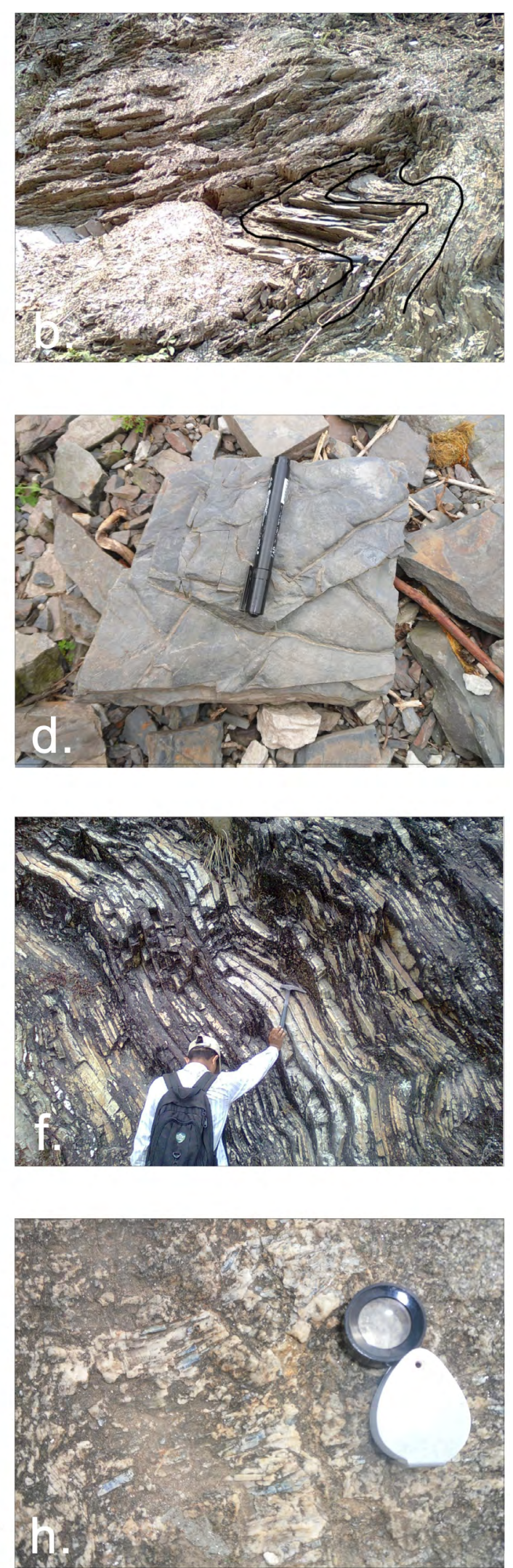

Fig. 3: Field photographs of the study area. a. Cross-lamination observed in quartzite of the Raguwa Formation, b. S-type of folds observed in the Raguwa Formation, c. Wave ripple observed in the Sanguri Quartzite, d. Mudcrack observed in the slate of the Karkichhap Formation, e. Superimposed fold observed in the dolomite of the Patigau Formation, f. Majite Quartzite observed at the Bhedetar-Rajarani road, g. Swell and pinch structure observed in the Patigau Formation, h. Blue coloured Kyanite blade observed in the banded gneiss of the Higher Himalayan crystalline. 


\section{Major Structures}

The major structures established by geological mapping basically include faults, folds, which are discussed on the following sub-headings.

\section{Thrusts}

The study area consists of four major thrust planes, viz. the Main Central Thrust (MCT), the Chimra Thrust (CT), the Chhotimorang Thrust (CMT) and the Main Boundary Thrust (MBT) from north to south.

\section{Main Central Thrust (MCT)}

The term 'Main Central Thrust' was first used in the Kumaon Himalaya of India by Heim and Gansser (1939). The MCT represents an important intracontinental subduction ductile sheared zone that accommodated a significant proportion of shortening between India and Asia during Tertiary Himalayan orogenesis (Macfarlane 1993). The most characteristics feature of the MCT is inverted metamorphism associated with the MCT zone (Le Fort 1975, Arita 1983). The MCT in the eastern Nepal can be defined as the tectonic discontinuity along which the Higher Himalayan thrust sheet has thrust to the south-southwest over the Lesser Himalayan metasediments
(Schelling 1992). The presence of MCT in the present study is determined by the relatively sharp lithological change and the change in isograde. The MCT is located in the north-east section of the study area, around the Lumphajun, the Patigaun and the Banpala village area (Fig. 2) where the kyanite bearing feldspathic schist and banded gneiss was first observed. The Higher Himalayan Crystalline's thrusts over the south-west exposed Lesser Himalaya Sequence along the north-east dipping the MCT with dip amount $\sim 30^{\circ}$ (Figs. 2 and 4 ).

\section{Chimra Thrust (CT)}

The Chimra Thrust named after the Chimra village (Sunuwar 1993) lies at the central part of the study area (Fig. 2). It extends in north-west to south-east direction and generally dips towards north-east direction with dip amount $\sim 45^{\circ}$. This thrust is well observed around the Ukhu Bajar, the Temban, the Olantar, the Kamphok village and the Leuti Khola area (Fig. 2) where the mylonitic schist with sheared quartz veins are observed with a change in the metamorphic grade from chlorite to biotite. It separates the Lesser Himalayan Sequence rocks into two groups' viz. the Bhedetar Group and the Dada Bajar Group exhibiting discordant and concordant relationship, respectively.
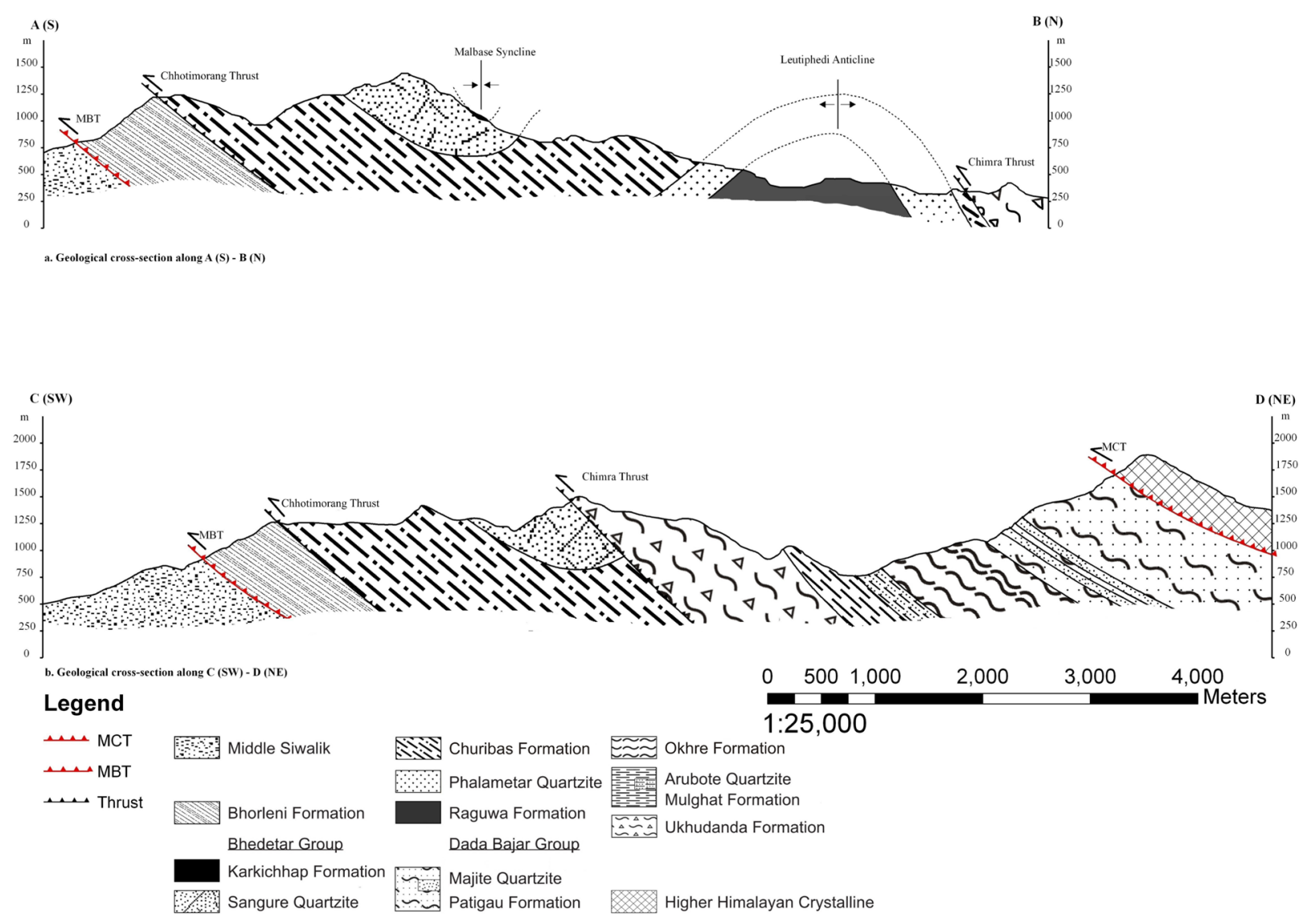

Fig. 4: Geological cross-section of the Dharan-Mulghat area. 


\section{Chhotimorang Thrust (CMT)}

The Chhotimorang Thrust is named after the Chhotimorang village situated south to Bhedetar along the Koshi Highway. This thrust lies on the south-western part of the study area and separates the Bhorleni Formation from the rocks of the Bhedetar Group. This thrust is observed along the foot-trail from Bhedetar to the Shikarbas village where there is an abrupt change in the lithology. It extends from west to southeast and dips toward north to north-east with dip amount $\sim 40^{\circ}$. This thrust can be compared with the Asganga Thrust of the Tribeni-Barahakshetra area which separates the Barahakshetra Group from the Tribeni Supergroup (Sunuwar 1993).

\section{Main Boundary Thrust (MBT)}

The Main Boundary Thrust is the steep northward dipping reverse fault along which the metasedimentary rocks of the Lesser Himalayan thrust over the Siwalik sedimentary rocks. According to Schelling and Arita (1991), the MBT must be flattened at the depth, as it approaches the underlying Main Detachment Fault (MDF). The Main Boundary Thrust is located in the south-west section of the study area (Fig. 2) around the Shikarbas Village, which extends from north-west to south-east and dips toward north-east with dip amount $35^{\circ}$. It is well observed along the Seuti Khola, Nisane Khola and the Sardhu Khola. In the study area the metasedimentary rocks of the Bhorleni Formation thrust over the sedimentary rocks of Siwaliks.

\section{Major Folds}

The study area consists of two macroscopic folds, viz. the Malbase Syncline and the Leutiphedi Anticline. Sunuwar (1993) named these macroscopic folds as the Ahale Syncline and the Phasuwa Anticline in the Barahakshetra-Tribeni area, west to the present study area.

\section{Malbase Syncline}

The Malbase Syncline is named after the Malbase village located along the Koshi Highway. This syncline extends almost east to west along the Malbase and the Dadatol village. Its eastern extension is discordantly cut by the Chimra Thrust along the Simsuwa Khola (Fig. 2). The Malbase Syncline forms north dip axial plane enclosing the rocks of the Karkichhap Formation in the core. The outer limb of the syncline is made up of the Karkichhap Formation, the Sangure Quartzite and the Churibas Formation. The southern limb of this syncline dips towards north to north-east with dip amount ranging from $20^{\circ}$ to $60^{\circ}$ and northern limb dips towards south to south-west with dip ranging from $30^{\circ}$ to $75^{\circ}$. The trend and plunge of the fold axis is $096^{\circ} / 09^{\circ}$ (Fig. 5).

\section{Leutiphedi Anticline}

The Leutiphedi Anticline is named after the Leutiphedi village situated along the Koshi Highway on the left bank of the Leuti Khola. This Leutiphedi Anticline extends almost

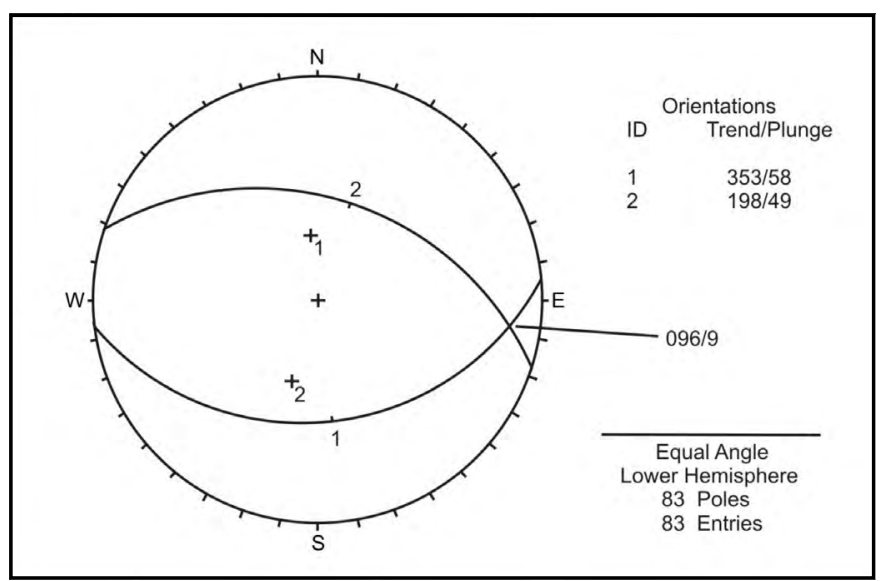

Fig. 5: Stereographic projection (lower hemisphere) of the pole to the foliation, part of the Malbase syncline, with best fit great circles for poles of the fold limbs.

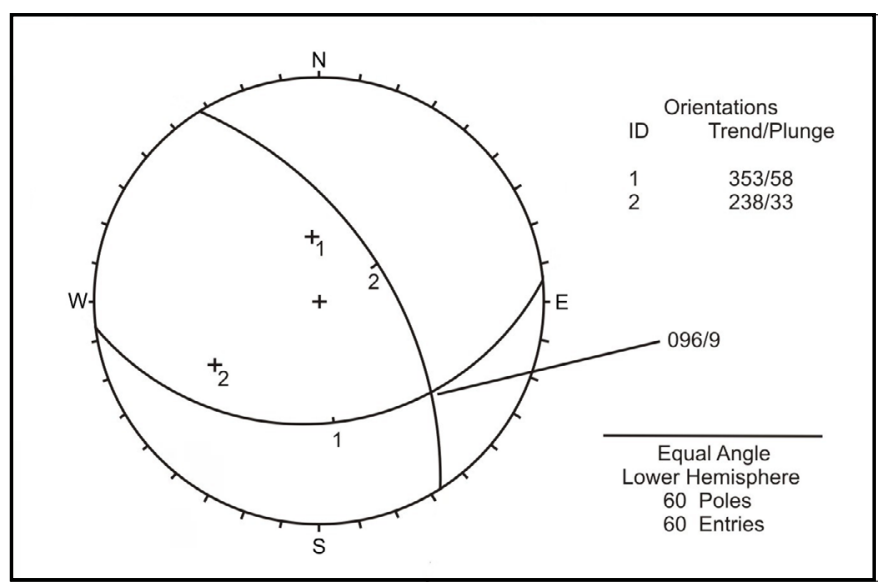

Fig. 6: Stereographic projection (lower hemisphere) of the pole to the foliation, part of the Leutiphedi Anticline, with best fit great circles for poles of the fold limbs.

north-west to south east along the Leutiphedi and the Askot village (Fig. 2). Its eastern extension is discordantly cut by the Chimra Thrust near the Phalametar village. The Leutiphedi Anticline forms south-west dip axial plane enclosing the rocks of the Raguwa Formation in the core. The outer limb of the Anticline is made up of the Raguwa Formation, the Phalametar Quartzite and the Churibas Formation. The northern limb of the anticline dips towards north-east with dip amount ranging from $45^{\circ}$ to $75^{\circ}$ and southern limb dips towards south-west with dip amount ranging from $30^{\circ}$ to $75^{\circ}$. The trend and plunge of the fold axis is $131^{\circ} / 24^{\circ}$ (Fig. 6).

\section{Microstructures}

The study of thin-sections of the rock reveals important structural characteristics that constitute the rock microstructure or fabric. These can be used not only to reconstruct the structural and metamorphic history of an area, but also to improve our understanding of deformation and metamorphic processes (Passchier and Trouw 2005). Thrust Faults are usually defined by the presence of older lithological units over the younger lithological units. The older rocks lying at the deeper level 

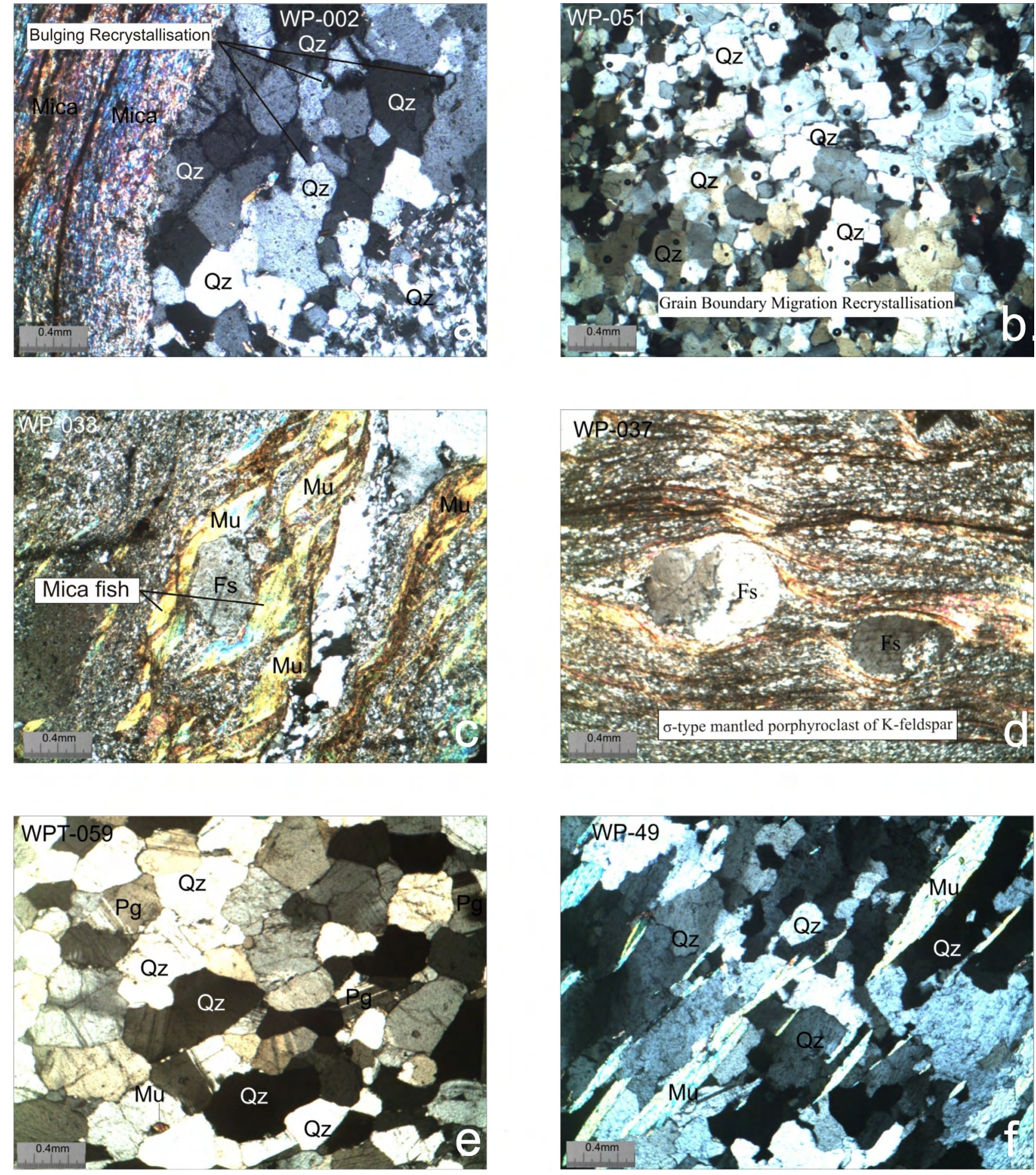

Fig. 7: Photomicrograph (UCN, 4x10) of sample used for microstructure study from study area. a. Dynamically recrystallized quartz grains of Phalametar Quartzite near CT, b. Polycrystalline quartz grains with irregular grain boundaries in quartzite of Patigau Formation, c. Mylonitic schist showing mica fish arranged between C'-type shear bands, senistral shear sense of Ukhudanda Formation, d. Mylonitic schist with $\sigma$-type mantled porphyroclast of K-feldspar in a matrix of mica and recrystallised quartz of Ukhudanda Formation, e. Banded gneiss showing polygonal fabric of quartz and feldspar grains formed by static recrystallization of Higher Himalayan Crystallines, f. Exaggerate quartzgrain microstructure in the Banded gneiss of Higher Himalayan Crystalline.

than the younger rocks experience high P-T condition. So their rheological properties should be different. In the course of thrusting the footwall is intensely bulldozed by the hanging wall. Due to the difference in this rheological properties and the deformation intensity at the footwall and hanging wall, the resultant microstructure should also differ in the footwall and 
hanging wall of the thrust. Paudel annd Arita (2002) reported difference in the deformation intensity between the Lesser Himalaya and the Higher Himalayan Crystalline along the Seti Khola Section.

Quartz is very sensitive to deformation and displays various microstructures. The deformation process and resultant microstructures of quartz are widely dependent upon temperature, interstitial fluids, grain size and mineralogy of matrix phase (Passchier and Trouw 2005).

Microstructures of quartz grain were compared in the quartzite, mylonitic schist and banded gneiss of the Lesser Himalaya and HHC along the Leuti Khola section and the Bhedetar-Rajarani road section. In thin section of quartzite of the Phalametar Quartzite, quartz grain shows the bulging of small new grain (Fig. 7a) which occurs at low temperature, this bulge separates from the host grain to form small new independent grain (Passchier and Trouw 2005). The quartz grain in thin section of quartzite of the Patigau Formation shows the polycrystalline quartz grain with irregular grain boundary formed by grain boundary migration recrystallization (Fig.7b) and generally occurs at higher temperature (Passchier and Trouw 2005). The mylonitic schist of Ukhudanda Formation shows mica fish arranged between C-type shear bands, senistral shear sense (Fig. 7c) and $\sigma$-type mantled porphyroclast of $\mathrm{K}$-feldspar in a matrix of mica and recrystallised quartz (Fig. 7d) showing the evidence of strong ductile deformation along the Chimra Thrust. In contrast to the intense deformation, shearing and dynamic recrystallization also known as primary recrystallization in the Lesser Himalayan rock, the Higher Himalayan Crystalline rocks shows quartz grain with straight or smoothly curved grain boundaries (Fig. 7e) formed by the Grain Boundary Area Reduction process, which is the principal mechanism of static recrystallization also known as secondary recrystallization. Most of the rock of HHC shows exaggerated grain growth microstructures (Fig. 7f).

\section{CONCLUSION}

The present study leads to the following conclusions:

The Dharan-Mulghat area can be divided into three tectonic units: the Higher Himalayan Crystallines, the Lesser Himalayan Sequence and the Siwaliks separated by the Main Central Thrust and Main Boundary Thrust, respectively.

The Lesser Himalayan Sequence is divided into ten formations, which are further grouped into two group and one individual formation: the Bhorleni Formation as an individual formation, the Karkichhap Formation; the Sangure Quartzite; the Churibas Formation; the Phalametar Quartzite; the Raguwa Formation as Bhedetar Group and the Patigau Formation, the Okhre Formation, the Mulghat Formation, and the Ukhudanda Formation as Danda Bajar Group.

The Main Central Thrust, the Chimra Thrust, the Chhotimorang Thrust and the Main Boundary Thrust are the major faults in the area. The Chimra Thrust separates the rocks of the Dada Bajar Group from the rocks of the Bhedetar Group.
The Chhotimorang Thrust separates the rocks of the Bhedetar Group from the rocks of the Bhorleni Formation.

The Leutiphedi Anticline and the Malbase Syncline are the major folds in the study area plunging towards east. The trend/ plunge of anticline and syncline are $131^{\circ} / 24^{\circ}$ and $096^{\circ} / 09^{\circ}$ respectively.

The study of quartz grain microstructures in thin section shows the dynamic recrystallization in the rocks of Lesser Himalayan Sequences, whereas the rocks of Higher Himalayan Crystallines show static recrystallization.

\section{ACKNOWLEDGEMENTS}

LKR is thankful to Mitra Rai Memorial Student Research Grant for providing a partial fund to carry out this work. The authors would like to thank Saunak Bhandari for his help in the field work.

\section{REFERENCES}

Arita, K., 1983, Origin of the inverted metamorphism of the Lower Himalayas, central Nepal. Tectonophysics, v. 95, pp. 43-60.

Bashyal, R. P., 1978, Gondwana type of formation with phosphatic rocks in south-east Nepal. Jour. Geol. Soc. India, v. 21, pp. 489491.

Bordet, P., 1961, In: Researches géologiques dans 1 'Himalaya du Népal région du Makalu. Paris Editions du Centre National dela Recherche Scientifique, Paris, $275 \mathrm{p}$.

Dhital, M. R., 2015, Geology of the Nepal Himalaya. Regional Perspective of the Classic Collided Orogen, Springer, Switzerland, $499 \mathrm{p}$.

Dhital, M. R. and Kizaki, K., 1987, Lithology and Stratigraphy of the northern Dang, Lesser Himalaya. Bull. College Sci., University of the Ryukyus, No. 45, pp. 183-244

Gansser, A., 1964, Geology of the Himalayas. Interscience, London, $289 \mathrm{p}$.

Hashimoto, S., Ohta, Y. and Akiba, C., 1973, Geology of Nepal Himalayas. Saikon Publ., Sapporo, 292 p.

Heim, A., and Gansser, A., 1939, Central Himalaya. Geological observation of the Swiss expedition 1936. Mémories de la Société Helvétique des Sciences Naturelles, Zürich. v. 73, 245p.

Le Fort, P., 1975, Himalayas; The Collided Range: Present Knowledge of the Continental Arc. American Jour. Sci., v. 275(A), pp. 1-44.

Macfarlane, A. M., 1993, Chronology of tectonic events in crystalline core of the Himalaya, Langtang National Park, central Nepal. Tectonics, v. 12, pp. 1004-1025.

Maskey, N. D., 1987, Regional Geochemistry and Geology of Parts of Dhankuta, Sunsari and Bhojpur District. Dept of Mines and Geol., Lainchour, Kathmandu.

Passchier, C. W. and Trouw, R. A., 2005, Microtectonics, Springer, Berlin, 366 p.

Paudel, L. and Arita, K., 2002, Locating the Main Central Thrust in central Nepal using lithologic, microstructural and metamorphic criteria. Jour. Nepal Geol. Soc., v. 26, pp. 29-42.

Sakai, H., 1983, Geology of the Tansen Group of the Lesser Himalaya in Nepal. Mem. Fac. Sci., Kyushu University, Ser. D, Geol., v. 25(1), pp. 27-74. 
Sakai, H., 1985, Geology of the Kali Gandaki Supergroup of the Lesser Himalayas in Nepal. Mem. Fac. Sci., Kyushu University, v. 25(3), pp. 337-397.

Stöcklin, J., 1980, Geology of Nepal and its regional frame. Jour. Geol. Soc. London, 137, pp. 1-34.

Stöcklin, J. and Bhattarai, K. D., 1977, Geology of the Kathmandu area and central Mahabharat range, Nepal Himalaya. Report of Dept of Mines and Geol.,/UNDP (unpublished), 86 p.

Schelling, D., 1992, The tectonostratigraphy and structure of the Eastern Nepal Himalaya. Tectonics, v. 11, pp. 925-943.

Schelling, D., Arita. K., 1991, Thrust tectonics, crustal shortening, and the structure of the far-eastern Nepal, Nepal Himalaya. Tectonics, v. 10, pp. 851-862.

Sunuwar, S.C., 1993, Geology of Tribeni-Barahakshetra area, Sunsari-Dhankuta district, eastern Nepal. M. Sc. Thesis, Central Dept. of Geology, Tribhuvan University, Nepal.

Tater, J. M., 1964, Geology of a portion of the Arun valley (Eastern Nepal). Nepal., Geol. Surv., Kathmandu.

Timsina, C., 2011, Seismic hazard assessment of the Dhankuta Municipality, Eastern Nepal. M.Sc., Thesis, Central Department of Geology, Tribhuvan University, Kathmandu, Nepal.

Valdiya K. S., 1980, The two Intracrustal Boundary Thrusts of the Himalaya. Tectonophysics, v. 66, pp. 323-348. 
